\title{
THE EFFECT OF SOME NATURAL PLANT OILS ON THE ISOLATED MOULD SPECIES FROM SOME MEAT PRODUCTS
}

\author{
AMAL R. FAWY HASSAN ${ }^{1}$ and NAHED M. ABDELAZIZ ${ }^{2}$ \\ ${ }^{1}$ B.V. Sc., Fac. Vet. Med., South Valley University, Qena, Egypt. \\ 2 Department of Food Hygiene, Fac. of Vet. Med., Sohag University, Sohag, Egypt.
}

Received: 28 December 2015; Accepted: 18 January 2016

\begin{abstract}
In the present study three natural plant oils (Clove, Cumin and Garlic oils) were used to study their effect on different isolated mold spp. that isolated from 100 samples of meat products ( 25 of each of beef luncheon, frozen minced meat, frozen sausage and basterma) which was collected from supermarkets of different sanitation levels in Qena Governorate. The isolated mold were (A. niger, A. flavus, A. terreus, A.carenus, A.ocraceous, A.versicolour, Cladosporiummuscae, Penicilliumcryzogenum and Rhizopus). The obtained results showed that A. niger was not affected by any of oils used in this investigation. A.Versicolour was affected only by Clove and Cumin oils mixture. A. flavus was inhibited by clove oil and mixtures of oils containing clove oil. While, A. carenus was inhibited by all oils except the Garlic oil. Also A. ocraceous was inhibited by all oils except the mixture of Cumin with Garlic oils. In conclusion, we recommended that using of Clove oil alone or mixed with Cumin oil in meat product processing as a way to prevent the growth of most molds and consequently we can avoid it's public health hazards and economic losses.
\end{abstract}

Key words: Clove, Cumin, Garlic, Meat products.

\section{INTRODUCTION}

A variety of microorganisms can lead to food spoilage in the food industry. So far, many pathogenic molds, such as Fusarium spp., Aspergillus spp., Penicillium spp. and Rhizopus spp., have been reported as the causal agents of foodborne diseases and/or food spoilage (Betts et al., 1999).

Spices and herbs have been added to food since ancient times, not only as flavoring agents, but also as folk medicine and food preservatives (Nakatani, 1994). Increasing of infections based on antibiotic resistant microorganisms and increasing consicious food consumers have to be using new and natural antimicrobials (Duman-Aydin, 2008).

Essential oils extracted from spices, as natural antimicrobial agents, attract particular attention due to their possible role in food protection from microorganisms, and their nontoxicity, in contrast to the synthetic preservatives (Suncica et al., 2009).

Corresponding author: Dr. NAHED M. ABDELAZIZ

E-mail address: Nahedvet2012@yahoo.com

Present address: Department of Food Hygiene, Fac. of Vet. Med., Sohag University, Sohag, Egypt.
In recent years, there has been an increasing interest for the application of essential oils, obtained from spices and other herbs, as alternative antimicrobial agents in food for human nutrition. Also, the advantage of spice extracts is that they do not contain microorganisms which contaminate natural spices (Karan et al., 2005).

It is well established that these extracts (anise, cumin, dalamagiasage, dill, fennel, laurel, mint, oregano, pickling herb, rosemary, sage, summer savory, sea fennel, sumac and black thyme) have antimicrobial properties against bacteria, molds and yeasts (Farag et al., 1989; Dorman and Svoboda, 2000; Ozcan and Erkmen, 2001; Sagdic and Ozcan, 2003).

\section{Aim of the work:-}

Study the effect of some natural oils on viability of different mold spp. isolated from beef luncheon, frozen minced meat, frozen sausage and basterma.

\section{MATERIALS AND METHODS}

\section{1- Collection of the samples}

A total of 100 random samples of beef luncheon, frozen minced meat, frozen sausage and basterma (25 samples of each) were collected from 
supermarkets of different sanitation levels in Qena Governorate (Qena, Dishna And Nag-Hamadi).

\section{2- Isolation and identification of the samples}

The samples were prepared according to (Jonson et al., 1959). Isolated and identification of mold was carried out according to (Al-Doory., 1980).

\section{3- Addition of natural plant oils (Shibat El-Hamd,} 2007):

Three of natural plant oils (clove, cumin and garlic oils) were used for studying their effect on nine species of the isolated and identified fungi.
A loopful of the tested fungal culture was mixed in $0.2 \mathrm{ml}$ (conc. $100 \%$ ). of each of natural plant oils for 2 hours before inoculation on modified sabouraud's dextrose agar media, the inoculated plates were incubated at $37^{\circ} \mathrm{c}$., for 48 hours. After that, the effect of the natural plant oils were noticed on the growth of the cultured tested fungi.

By the same manner the effect of mixtures (conc. $50 \%$ of each oil) (clove with cumin, clove with garlic and garlic with cumin) and a mixture of the all oils (clove with cumin and garlic) was noticed on the growth of the cultured tested fungi.

\section{RESULTS}

Table 1: The effect of some natural plant oils on the isolated mould species.

\begin{tabular}{|c|c|c|c|c|c|c|c|}
\hline \multirow[t]{2}{*}{ Fungal species } & \multicolumn{7}{|c|}{ Natural plant oils } \\
\hline & $\begin{array}{c}\text { Clove } \\
\text { oil }\end{array}$ & $\begin{array}{c}\text { Cumin } \\
\text { oil }\end{array}$ & $\begin{array}{c}\text { Garlic } \\
\text { oil }\end{array}$ & $\begin{array}{c}\text { Clove + } \\
\text { Cumin } \\
\text { oil }\end{array}$ & $\begin{array}{c}\text { Cumin }+ \\
\text { Garlic oil }\end{array}$ & $\begin{array}{c}\text { Clove + } \\
\text { Garlic oil }\end{array}$ & $\begin{array}{c}\text { Clove+ } \\
\text { Cumin } \\
+ \text { Garlic oil }\end{array}$ \\
\hline A. niger & -ve & -ve & -ve & -ve & -ve & -ve & -ve \\
\hline Petromycesflavus (A. flavus) & $+\mathrm{ve}$ & -ve & -ve & $+\mathrm{ve}$ & -ve & $+\mathrm{ve}$ & $+\mathrm{ve}$ \\
\hline A. terreus & $+\mathrm{ve}$ & -ve & -ve & $\mathrm{ve}+$ & -ve & -ve & $+\mathrm{ve}$ \\
\hline A.carenus & +ve & +ve & -ve & +ve & $+\mathrm{ve}$ & +ve & +ve \\
\hline A. ocraceous & $+\mathrm{ve}$ & + ve & +ve & $+\mathrm{ve}$ & -ve & $+\mathrm{ve}$ & $+\mathrm{ve}$ \\
\hline A.versicolour & -ve & -ve & -ve & + ve & -ve & -ve & -ve \\
\hline Penecilliumcryzogenum & +ve & +ve & -ve & -ve & -ve & $+\mathrm{ve}$ & +ve \\
\hline Rhizopus & $+\mathrm{ve}$ & $+\mathrm{ve}$ & -ve & $+\mathrm{ve}$ & +ve & $+\mathrm{ve}$ & -ve \\
\hline Cladosporiummuscae & $+\mathrm{ve}$ & -ve & + ve & $+\mathrm{ve}$ & -ve & + ve & $+\mathrm{ve}$ \\
\hline Percentage $(\%)$ of effect & $77.7 \%$ & $44.4 \%$ & $22.2 \%$ & $77.7 \%$ & $22.2 \%$ & $66.6 \%$ & $66.6 \%$ \\
\hline
\end{tabular}

$+\mathrm{ve} \rightarrow$ referring to absence of the fungus.

-ve $\rightarrow$ referring to presence of the

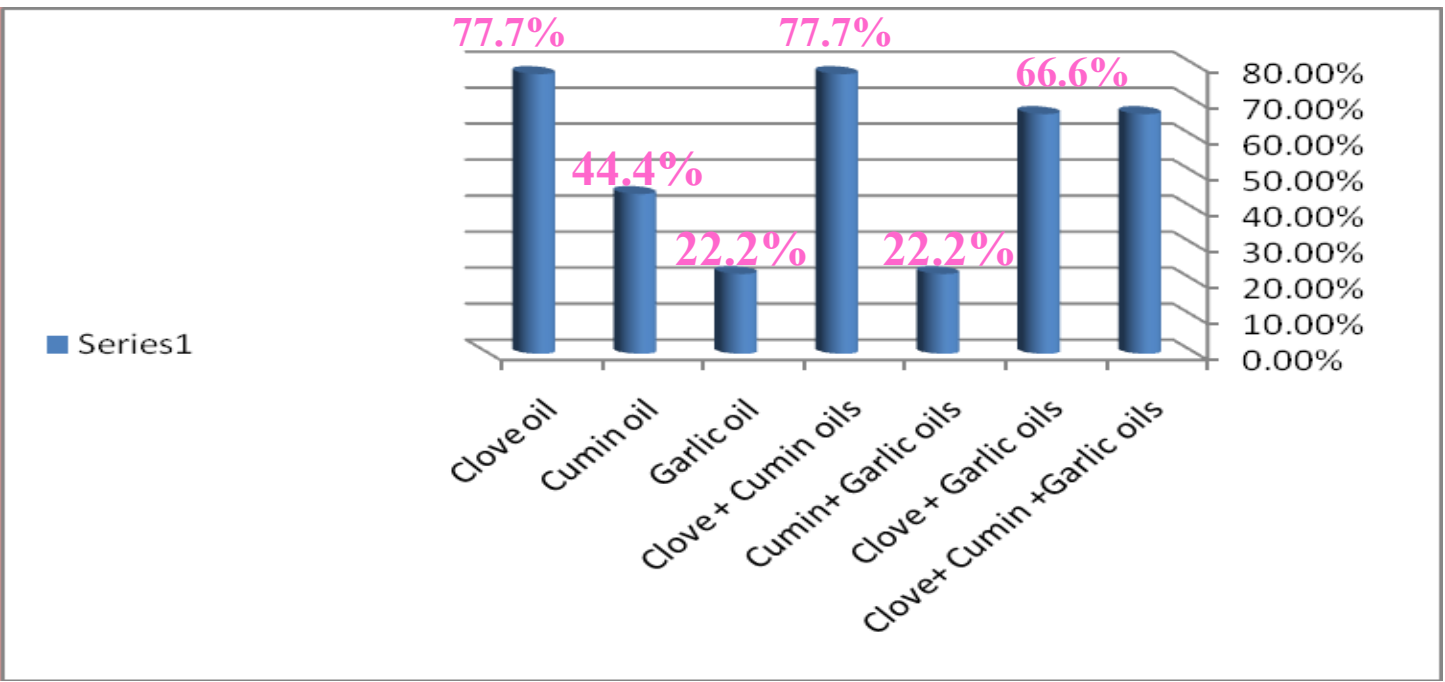

Fig. 1: Effect of natural plant oils on the isolated fungal species. 


\section{DISCUSSION}

From the results obtained in Table (1), it was found that Clove, Cumin and Garlic oils affected on the isolated mold spp. in different percentages $(77.7 \%$, $44.4 \%$ and $22.2 \%$ ) for each of them, respectively.

Mixing of these oils (Clove with Cumin oils), (Cumin with Garlic oils), (Clove with Garlic oils) and (Clove with Cumin and Garlic oils) also affect the growth of isolated mold spp. by $77.7 \%, 22.2 \%, 66.6 \%$ and $66.6 \%$, respectively.

It was found that Clove oil prevent the growth of all tested mould spp. Except A. niger and A. versicolour which not affected by Clove oil.

The result recorded in this study differed from data obtained by Shibat El-Hamd, (2007) who told that Clove oil inhibited the growth of all tested mold. Including A. niger.

When Clove oil mixed with Cumin oil it gave the same percentage of efficacy as Clove oil alone $(77.7 \%)$, that because of this mixture could inhibit the growth of all tested molds except A. niger and Penicilliumcryzogenum that show no inhibition when treated by this mixture.

Cumin oil show different percentage of efficacy that it affect only $44.4 \%$ of tested molds including $A$. carenus, A. ocraceous. P. cryzogenum and Rhizopus. other testedmold spp. were not affected by Cumin oil. Shibat El-Hamd, (2007) indicated that Cumin oil was the most effective oil against $A$. flavus and gave moderate effect on $A$. terreus growth on culture media. That differ than the present results as it was founded that Cumin oil not affect A. flavus or $A$. terreus growth on culture media.

Garlic oil comes at last on it's efficacy against the tested mold spp. as it only affect $22.2 \%$ of the tested molds including $A$. ocraceous and Cladosporiummuscae whereas other Aspergillus spp., $P$. cryzogenum and Rhizopus were not affected by Garlic oil also. This result recorded in this study differed from data obtained by Shibat El-Hamd, (2007) who proved that Garlic oil affect moderately against A.terreus and slightly against $A$. niger and $A$. flavus.

Cumin and Garlic oils mixture also affect only $22.2 \%$ against the tested mold spp. Including $A$. carenus and Rhizopus whereas other Aspergillus spp., $P$. cryzogenum and Cladosporiummuscae were not affected by this mixture.

Clove and Garlic oils mixture affect $66.6 \%$ of tested moldspp. Only A. niger, A. terreus and A. Versicolour were not affected but other Aspergillus spp., $P$. cryzogenum, Cladosporiummuscae and Rhizopus were inhibited by Clove and Garlic oils mixture.

When all oils are mixed, only A. niger, A. versicolour and Rhizopus were not affected but other Aspergillus spp., P. cryzogenum and Cladosporiummuscae were inhibited by the three oils mixture. This may beattributed to the varies of concentration of each oil prepared in the mixture.

From these abovementioned results from Table (1) it was noticed that $A$. niger was not affected by any of oils used in this investigation. A.Versicolour was not affectedexcept by Clove with Cumin oils mixture. $A$. flavus was inhibited by clove oil and mixtures of oils containing clove oil. While A. carenus was inhibited by all oils except the Garlic oil. A.ocraceous was inhibited by all oils except the mixture of Cumin with Garlic oils.

From all mentioned results it is worth to be mentioned that Clove oil alone or with mixing with Cumin oil is the most effective oil against most mold spp. under investigation.

It is well known that mycotoxins produced by mycotoxogenic fungi in food materials wouldn't be removed from food even if the fungi were removed or killed, so it is important to prevent-from the first- the growth of fungi in food or feed to avoid presence of mycotoxins. That may occur by adding some fungal inhibiting food addetives as natural plant oils (as Clove oil only or mixed with Cumin oil) because the old saying, the" growth of fungi in foods is acceptable or even good as it just means production of penicillin", has become unacceptable Filtenborg, (1992)

\section{REFRENCES}

Al-Doory, $\quad$ Y. (1980): Laboratory Medical Mycologylea and Febiger Philadelphia. Kimptonpuplishers, London.

Betts, G.D.; Linton, P. and Betteridge, R.J. (1999): Food spoilage yeasts: Effects of $\mathrm{pH}, \mathrm{NaCl}$ and temperature on growth. Food Control 10, 1:2733.

Borenstein, M.; Rothstein, H. and Cohen, J. (1997): Sample power statistics 1.0.SPSS, Inc., Chicago.

Dorman, S.G. and Svoboda, K.P. (2000): Antimicrobial activity of summer savory (Saturejahortensis L.) essential oil and its constituents. J. Hortic. Sci., 64, 205-210.

Duman-Aydin, B. (2008): Investigation of Antibacterial Effects of Some Medicinal Plants and Spices on Food Pathogens. Kafkas Univ. Vet. Fak. Derg., 14, 83-87.

Farag, R.S.; Daw, Z.Y.; Hewedi, F.M. and El-Baroty, G.S.A. (1989): Antimicrobialactivity of some 
Egyptian spice essential oils. J. Food Protect., 52, 665-667.

Filtenborg, $O$. (1992): Mycology and mycotoxins. in $3^{\text {rd }}$ world congress. Foodborne infections and intoxications, 16-19 June, Berlin.

Jonson, L.F.; Curl, E.A.; Bond, J.H. and Fribourg, H.A. (1959): Method for studying soil microfloraplant disease relationships. Minneapoils: Burgress publishing company.

Karan, D.; Vukojeviã, J.; Miliãeviã, D.; Ljajeviã Grbiã, M. and Jan-koviã, V. (2005): Presence of moulds and mycotoxins in spices, Matica Srpska Proceedings for Natural Science, 108: 77-85.

Nakatani, N. (1994): Antioxidative and antimicrobial constituents of herbs andspices. In: Spices, herbs and edible fungi (Ed.: G. Charambous). Elsevier Science, New York. pp. 251-271.
Ozcan, M. and Erkmen, O. (2001): Antimicrobial activity of essential oils of Turkishplant spices. Eur. Food Res. Technol., 212, 658-660.

Sagdic, O. and Ozcan, M. (2003): Antibacterial activity of Turkish spice hydrosols. Food Control., 14, 141-143.

Shibat El-Hamd, M.D. (2007): Some studies on poultry mycosis in Qena governorate. M.V.Sc. Thesis. Poultry Diseases Department, Fac. Vet. Med. Assiut Univ.

Suncica D. Kocia-Tanackov; Gordana R. Dimic; Alexandra N. Tepic and Biserka L. Vujicic. (2009): Influence of alliumampeloprasuml and allium cepa 1 . essential oils on the growth of some yeasts and moulds. Proc. Nat. Sci, Matica Srpska Novi Sad, 116, 121-130.

\section{تأثير بعض الزيوث النباتية الطبيعية على نمو الفطريات المعزولة من بعض منتجات اللحوم \\ أمل رمضان فاوى حسن ، نـاهد محمود عبل العزيز}

E-mail: Nahedvet2012@yahoo.com

Assiut University web-site: www.aun.edu.eg

في الدراسة الحالية نم استخدام ثلاثة من الزيوت النباتية الطبيعية (القرنفل، الكمون والثوم) لدراسة تأثير ها علي نمو الفطريات

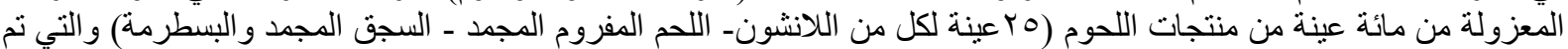

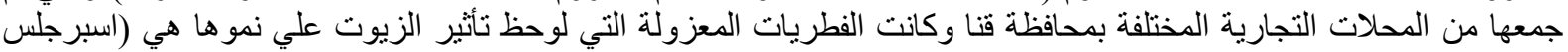

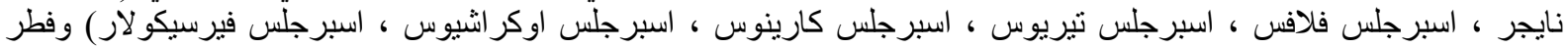

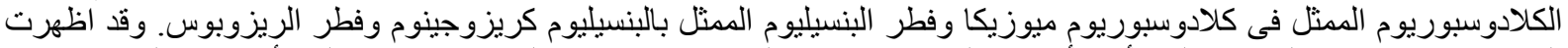

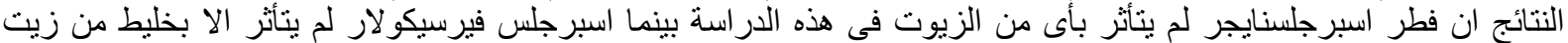

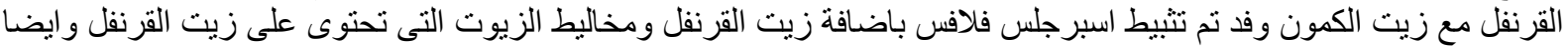

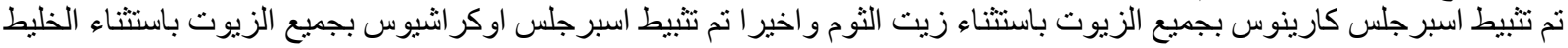

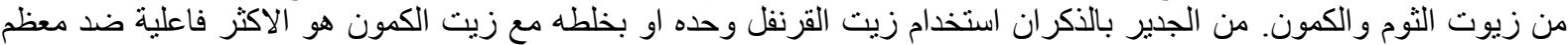

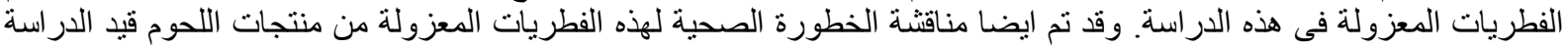

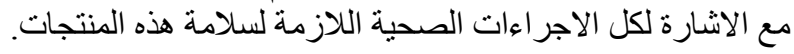

